\section{CHRYSOSPORIN, A NEW INHIBITOR OF 3-HYDROXY-3-METHYLGLUTARYL COENZYME A REDUCTASE PRODUCED BY Chrysosporium pannorum}

Sir:

Cholesterol is synthesized via more than 20 enzymatic reactions. This pathway is mainly regulated by the enzyme, 3-hydroxy-3-methylglutaryl coenzyme A (HMG-CoA) reductase ${ }^{1)}$. Recent clinical results have shown that HMG-CoA reductase inhibitors such as lovastatin ${ }^{2}$ (monacolin $\mathrm{K}^{3)}$ ) are safe and effective drugs for treatment of hypercholesterolemia ${ }^{4)}$.

We have previously reported that Chrysosporium pannorum M10539 produces an HMG-CoA reductase inhibitor, pannorin ${ }^{5)}$. Further study of the metabolites produced by this strain led to the isolation of another novel inhibitor designated chrysosporin. The present communication deals with the isolation, physico-chemical properties and biological activity of chrysosporin.

Chrysosporin was produced by growing $C$. pannorum $\mathrm{M} 10539$ at $25^{\circ} \mathrm{C}$ for 10 to 12 days in a medium containing $20 \%$ potato extract and $2 \%$ glucose. The cultural conditions were identical to those described previously for production of pannorin by this microbe ${ }^{5)}$, except that production medium was inoculated with $2 \%$ ( $\mathrm{vol} / \mathrm{vol})$ of seed culture. The cultue filtrate ( 5 liters) was adjusted to pH 2.5 with $\mathrm{HCl}$ and extracted three times with 2 liters of ethyl acetate. The organic extracts were combined and concentrated to 1 liter, followed by extracting three times with 1 liter of $5 \% \mathrm{NaHCO}_{3}$ (pH 8.2). The aqueous layer was pooled and adjusted to $\mathrm{pH} 2.5$ with $\mathrm{HCl}$. Precipitates formed were collected by centrifugation, washed with water and then lyophilized, giving $5.53 \mathrm{~g}$ of a brownish residue. The residue was suspended with $100 \mathrm{ml}$ of water and extracted three times with $100 \mathrm{ml}$ of $n$-butyl acetate at $\mathrm{pH}$ 3. The solvent extracts were dried over sodium sulfate and concentrated to give $1.88 \mathrm{~g}$ of a brownish powder. The residue was dissolved in $19 \mathrm{ml}$

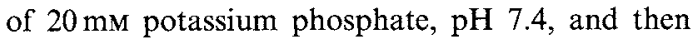
was submitted to gel filtration in 19 batches over a Bio-Gel P-6 column $(26 \times 40 \mathrm{~mm})$, which was equilibrated and developed with $20 \mathrm{~mm}$ potassium phosphate, $\mathrm{pH} 7.4$, containing $0.3 \mathrm{M} \mathrm{NaCl}$ and $0.02 \%$ sodium azide. Active fractions were pooled and extracted three times with an equal volume of ethyl acetate at $\mathrm{pH} 3$. The organic layer was dried over sodium sulfate and was concentrated to dryness, giving $310 \mathrm{mg}$ of a brownish powder. The residue was dissolved in $15.5 \mathrm{ml}$ of acetonitrile $-0.1 \%$ phosphoric acid $(2: 3)$ and was chromatographed using preparative HPLC on a silica ODS column $(10 \times 300 \mathrm{~mm})$ in 75 batches. The column was developed with acetonitrile $-0.1 \%$ phosphoric acid $(2: 3)$ at a flow rate of $6 \mathrm{ml} /$ minute. Active fractions were concentrated and extracted with ethyl acetate. The organic layer was dried over sodium sulfate and was concentrated to dryness to give $35 \mathrm{mg}$ of chrysosporin as a dark brown powder.

The physico-chemical properties of chrysosporin are summarized in Table 1 . The molecular formula of chrysosporin was determined to be $\mathrm{C}_{27} \mathrm{H}_{18} \mathrm{O}_{10}$ from the results of HRFAB-MS and ${ }^{13} \mathrm{C}$ NMR studies. The UV spectra of chrysosporin showed absorption maxima at $234,284,293$ and $376 \mathrm{~nm}$ in methanol, which were strongly affected under alkaline conditions (Table 1). The IR, ${ }^{1} \mathrm{H}$ NMR and

Table 1. Physico-chemical properties of chrysosporin.

\begin{tabular}{|c|c|}
\hline Appearance & Dark brown powder \\
\hline Molecular formula & $\mathrm{C}_{27} \mathrm{H}_{18} \mathrm{O}_{10}$ \\
\hline \multicolumn{2}{|l|}{ HRFAB-MS $(m / z)$} \\
\hline Found: & $501.0832(\mathrm{M}-\mathrm{H})^{+}$ \\
\hline Calcd: & 501.0827 for $\mathrm{C}_{27} \mathrm{H}_{17} \mathrm{O}_{10}$ \\
\hline \multicolumn{2}{|l|}{$\mathrm{UV} \lambda_{\max } \mathrm{nm}(\varepsilon)$} \\
\hline $\mathrm{MeOH}$ & $\begin{array}{r}234(32,000), 284(21,500) \\
293(23,000), 376(7,000)\end{array}$ \\
\hline $\mathrm{MeOH}-1 \mathrm{M} \mathrm{HCl}(4: 1)$ & $\begin{array}{l}232(34,800), 284(21,900) \\
292(25,300), 374(7,100) \\
\quad 420(3,200)\end{array}$ \\
\hline $\mathrm{MeOH}-\mathrm{I} \mathrm{M} \mathrm{NaOH}(4: 1)$ & $\begin{array}{r}248(26,300), 273(23,400) \\
290(21,500), 374(9,900)\end{array}$ \\
\hline IR $v_{\max }(\mathrm{KBr}) \mathrm{cm}^{-1}$ & $\begin{array}{l}3450,2930,1700,1684 \\
1676,1620,1600,1490 \\
1330,1280,1100,1050 \\
840\end{array}$ \\
\hline${ }^{1} \mathrm{H} \mathrm{NMR}^{\mathrm{a}} \delta$ & $\begin{array}{l}2.34(3 \mathrm{H}, \mathrm{s}), 2.54(3 \mathrm{H}, \mathrm{s}), \\
2.61(3 \mathrm{H}, \mathrm{s}), 5.55(1 \mathrm{H}, \\
\mathrm{s}), 6.67(1 \mathrm{H}, \mathrm{s}), 7.14 \\
(1 \mathrm{H}, \mathrm{s}), 7.57(1 \mathrm{H}, \mathrm{s}), \\
9.70(1 \mathrm{H}, \mathrm{br} \mathrm{s}), 9.97(1 \mathrm{H}, \\
\text { br s), } 12.17(1 \mathrm{H}, \mathrm{brs}), \\
12.87(1 \mathrm{H}, \mathrm{s})\end{array}$ \\
\hline${ }^{13} \mathrm{C} \mathrm{NMR}^{\mathrm{b}} \delta$ & $\begin{array}{c}19.04,23.40,31.55,88.93 \\
102.39,102.45,106.61 \\
107.46,112.81,117.84 \\
120.21,122.24,130.44 \\
132.45,136.21,136.25 \\
141.61,154.53,156.33 \\
156.44,156.71,158.35 \\
161.07,169.48,180.30 \\
189.93,203.07\end{array}$ \\
\hline
\end{tabular}

a DMSO- $d_{6}, 270 \mathrm{MHz}$.

b $\mathrm{DMSO}-d_{6}, 68 \mathrm{MHz}$. 
Fig. 1. Chrysosporin inhibition of (A) in vitro sterol biosynthesis from $\left[{ }^{14} \mathrm{C}\right]$ acetate and (B) HMG-CoA reductase activity.

Incorporation of $\left[{ }^{14} \mathrm{C}\right]$ acetate into cholesterol $(\bullet)$ and lanosterol $(0)$ and HMG-CoA reductase activity ( $\mathbf{\square})$ were determined in the presence of the indicated concentrations of chrysosporin using a rat liver cholesterol biosynthetic system and microsomes, respectively. Each value represents the average of duplicate determinations.

(A)

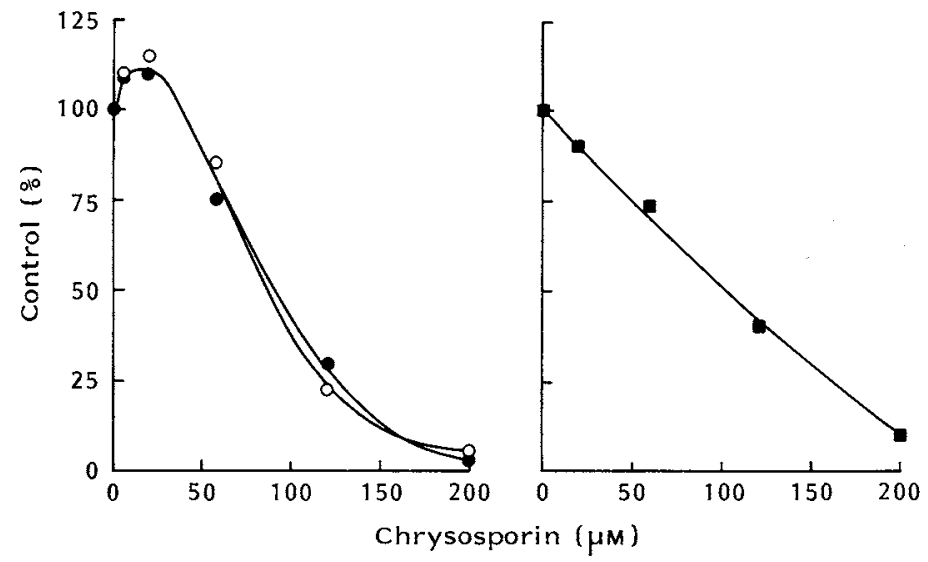

Fig. 2. Double reciprocal plots and Dixon plots (inset) for the inhibition of HMG-CoA reductase by chrysosporin.

Microsomal HMG-CoA reductase activity was determined in the presence of chrysosporin at concentrations of $0(\mathbf{E}), 90(\mathbf{\Delta})$ and $150 \mu \mathrm{M}(\bullet)$. In the inset, concentrations of $\left[{ }^{14} \mathrm{C}\right] \mathrm{HMG}-\mathrm{CoA}$ were $25(\square), 35(\bigcirc), 50(\nabla)$ and $100 \mu \mathrm{M}(\triangle)$. Each value represents the average of duplicate determinations.
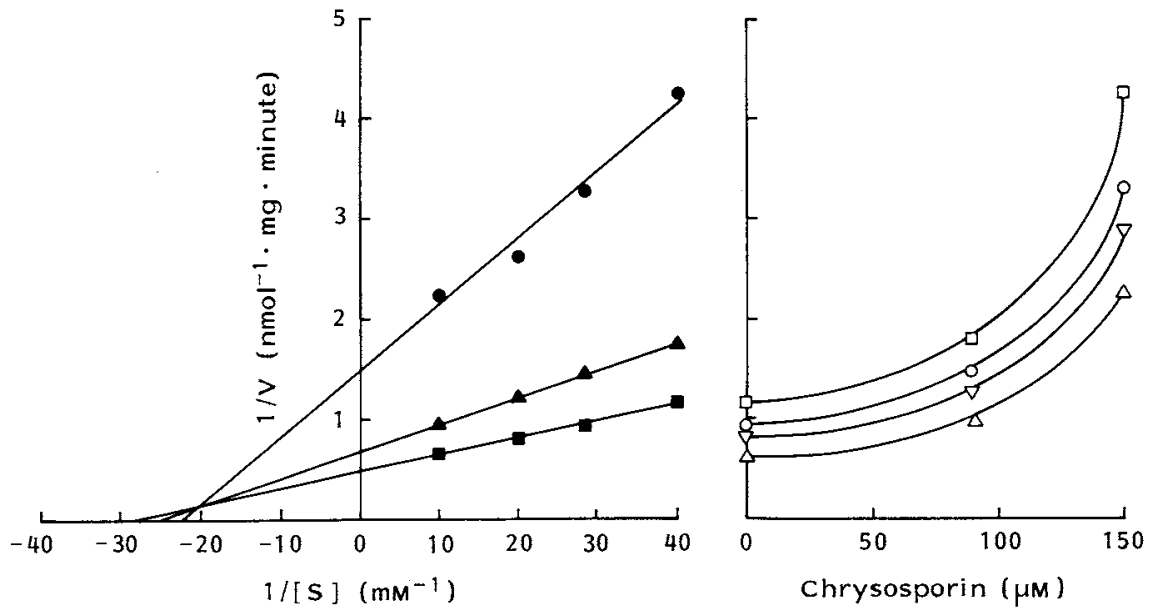

${ }^{13} \mathrm{C}$ NMR data are shown in Table 1 . These data suggested that chrysosporin is a novel compound closely related to pannorin, another HMG-CoA reductase inhibitor produced by $C$. pannorum ${ }^{5}$. Structure of chrysosporin is under investigation and will be reported elsewhere.
In vitro sterol synthesis and HMG-CoA reductase activities were determined using rat liver preparations as described previously ${ }^{6}$. Chrysosporin inhibited $\left[{ }^{14} \mathrm{C}\right]$ acetate incorporation into both cholesterol and lanosterol by $50 \%$ at a concentration of $80 \mu \mathrm{M}$ (Fig. 1A). Microsomal HMG-CoA 
Table 2. Irreversible inhibition of $\mathrm{HMG}-\mathrm{CoA}$ reductase by chrysosporin.

\begin{tabular}{ccc}
\hline \multirow{2}{*}{$\begin{array}{c}\text { Chrysosporin } \\
(\mu \mathrm{M})\end{array}$} & \multicolumn{2}{c}{$\begin{array}{c}\text { HMG-CoA reductase activity } \\
\text { (pmol/minute/mg) }\end{array}$} \\
\cline { 2 - 3 } & Before dialysis & After dialysis \\
\hline 0 & $853(100 \%)$ & $530(100 \%)$ \\
50 & $277(32 \%)$ & $268(51 \%)$ \\
100 & $132(16 \%)$ & $135(25 \%)$ \\
160 & $66(8 \%)$ & $92(17 \%)$ \\
\hline
\end{tabular}

Rat liver microsomes were incubated at $37^{\circ} \mathrm{C}$ for 10 minutes in $100 \mathrm{~mm}$ potassium phosphate, $\mathrm{pH} 7.4$, in the presence or absence of chrysosporin. HMG-CoA reductase activity in microsomes was determined before and after dialysis at $4^{\circ} \mathrm{C}$ for 20 hours against $100 \mathrm{mM}$ potassium phosphate, $\mathrm{pH} 7.4,10 \mathrm{~mm}$ EDTA and $2 \mathrm{~mm}$ dithiothreitol. Each value represents the average of duplicate determinations.

reductase activity was inhibited $50 \%$ by $100 \mu \mathrm{M}$ chrysosporin (Fig. 1B).

Double reciprocal plots ${ }^{7)}$ for HMG-CoA reductase inhibition by chrysosporin showed that the inhibition was the mixed type with respect to HMG-CoA, and Dixon plots ${ }^{7}$ curved upwards (Fig. 2 ), suggesting that the inhibition is cooperative or time-dependent. Reversibility of the inhibition was determined by dialysis. As shown in Table 2, HMG-CoA reductase activity was inhibited 70 $90 \%$ after 10 -minute preincubation with $50 \sim 160 \mu \mathrm{M}$ chrysosporin, and did not recover significantly from inhibition even after extensive dialysis of the microsomes. This result demonstrated that chrysosporin is an irreversible inhibitor of HMG-CoA reductase.

\section{Acknowledgment}

This work was supported in part by a Grant-in-Aid for Science Research from the Ministry of Science, Culture and Education, Japan.
JONG KoO PARK

KaOru SaKaI

Haruo Ogawa

KeIJi Hasumi

AKIRA ENDO

Department of Applied Biological Science, Tokyo Noko University, Fuchu, Tokyo 183, Japan

(Received March 3, 1993)

\section{References}

1) Goldstein, J. L. \& M. S. Brown: Regulation of mevalonate pathway. Nature 343: 425 430, 1990

2) Alberts, A. W.; J. Chen, G. Kuron, V. Hunt, J. Huff, C. HoffMan, J. Rothrock, M. LOPEZ, H. Joshua, E. Harris, A. Patchett, R. Monaghan, S. Currie, E. Stapley, G. Albers-Schonberg, O. Hensens, J. Hirshfield, K. HoOgsteen, J. Liesch \& J. SPRINGER: Mevinolin, a highly potent competitive inhibitor of hydroxymethylglutaryl-coenzyme A reductase and cholesterol-lowering agent. Proc. Natl. Acad. Sci. U.S.A. 77: 3957 3961, 1980

3) ENDo, A.: Monacolin K, a new hypocholesterolemic agent produced by a Monascus species. J. Antibiotics 32: 852 854, 1979

4) Hunninghake, D. B.: HMG-CoA reductase inhibitors. Curr. Opin. Lipidol. 3: 22 28, 1992

5) Ogawa, H.; K. Hasumi, K. Sakai, S. Murakawa \& A. ENDo: Pannorin, a new 3-hydroxy-3methylglutaryl coenzyme A reductase inhibitor produced by Chrysosporium pannorum. J. Antibiotics 44: 762 767, 1991

6) KuRoda, M. \& A. Endo: Inhibition of in vitro cholesterol synthesis by fatty acids. Biochim. Biophys. Acta 486: 70 81, 1977

7) Dixon, M. \& E. C. WebB: Enzyme inhibition and activation. In "Enzymes", 3rd Ed., pp. 332 467, Longman, London, 1979 